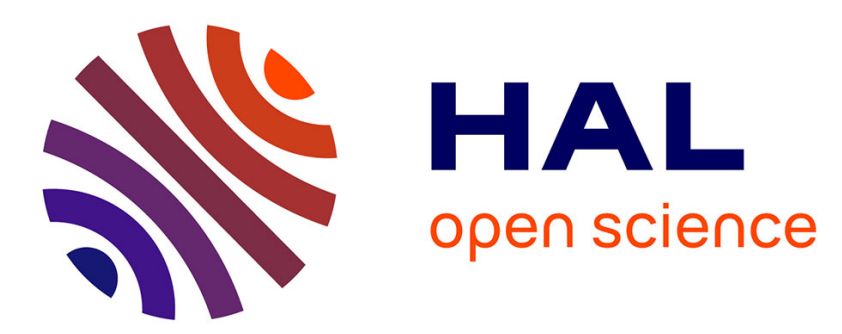

\title{
Annual fossil organic carbon delivery due to mechanical and chemical weathering of marly badlands areas
}

Y. Graz, Christian Di Giovanni, Yoann Copard, N. Mathys, A. Cras, V. Marc

\section{To cite this version:}

Y. Graz, Christian Di Giovanni, Yoann Copard, N. Mathys, A. Cras, et al.. Annual fossil organic carbon delivery due to mechanical and chemical weathering of marly badlands areas. Earth Surface Processes and Landforms, 2012, 37, pp.1263-1271. 10.1002/esp.3232 . insu-00782723

\section{HAL Id: insu-00782723 \\ https://hal-insu.archives-ouvertes.fr/insu-00782723}

Submitted on 19 Mar 2013

HAL is a multi-disciplinary open access archive for the deposit and dissemination of scientific research documents, whether they are published or not. The documents may come from teaching and research institutions in France or abroad, or from public or private research centers.
L'archive ouverte pluridisciplinaire HAL, est destinée au dépôt et à la diffusion de documents scientifiques de niveau recherche, publiés ou non, émanant des établissements d'enseignement et de recherche français ou étrangers, des laboratoires publics ou privés. 


\title{
Annual fossil organic carbon delivery due to mechanical and chemical
}

\section{weathering of marly badlands areas}

Yann Graz, ${ }^{a}$ Christian Di-Giovanni, ${ }^{a *}$ Yoann Copard, ${ }^{b}$ Nicolle Mathys, ${ }^{c}$ Alexandre Cras $^{\mathrm{d}}$ and Vincent Marc $^{\mathrm{d}}$

${ }^{a}$ Université d'Orléans, Université François Rabelais - Tours, CNRS/INSU Institut des Sciences de la Terre d'Orléans - UMR 6113, Campus Géosciences 1A rue de la Férollerie 45071 Orléans cedex 2. ${ }^{b}$ UMR CNRS 6143 M2C, University of Rouen, department of Earth Sciences, place E. Blondel, Bat. Irese A, Mont Saint Aignan Cedex, France.

${ }^{c}$ Cemagref Grenoble, Research Unit Erosion Torrentielle, Neige et Avalanches, BP 76, 38402 Saint Martin d'Hères, France.

${ }^{d}$ Laboratoire d'Hydrogéologie, Université d'Avignon, Faculté des Sciences, 33 rue Louis Pasteur, 84000 Avignon.

* Corresponding author: C. Di-Giovanni, Institut des Sciences de la terre d'Orléans, Université d'Orléans/Université François Rabelais de Tours, CNRS/INSU UMR 6113, $1 \mathrm{~A}$ rue de la Férollerie, 45072 Orléans, France. E-mail : Christian.Di-Giovanni@univ-orleans.fr; fax : (33)02-38-41-72-12

\begin{abstract}
A key issue in the study of the carbon cycle is to well constrain stocks and fluxes in and between C-reservoirs. Amongst these, the role and importance of Fossil Organic Carbon (FOC) release by weathering of outcropping sedimentary rocks on continental surfaces is still debated and lacks measured constraint. Our work focuses on FOC fluxes due to chemical and mechanical weathering of marls in two experimental watersheds showing a typical badlands geomorphology (Draix watersheds, Laval and Moulin, Alpes de Haute Provence, France). Organic matter from bedrocks, soil litters and riverine
\end{abstract}


particles are characterized by Rock-Eval 6 pyrolysis. FOC fluxes due to mechanical weathering are then estimated by monitoring the annual particulate solid exports at the outlets of the watersheds (1985-2005 period). FOC fluxes from chemical weathering were calculated using $\mathrm{Ca}^{2+}$ concentrations in dissolved loads (year 2002) to assess the amount of FOC released by the dissolution of carbonate matrix. Results show that FOC delivery is mainly driven by mechanical weathering, with a yield ranging from 30 to 59 $\mathrm{t} \mathrm{km}^{-2} \mathrm{yr}^{-1}$ in Moulin $\left(0.08 \mathrm{~km}^{2}\right)$ and Laval $\left(0.86 \mathrm{~km}^{2}\right)$ catchments respectively (19852005 average). The release of FOC attributed to chemical weathering reach 2.2 to $4.2 \mathrm{t}$ $\mathrm{km}^{-2}$ for the year 2002. These high FOC fluxes from badlands are similar to those observed in tectonically active mountain catchments. At a regional scale, badlands outcropping within the Durance watershed do not exceed $0.25 \%$ in area of the Rhône catchment, but could annually deliver $12000 \mathrm{t} \mathrm{yr}^{-1}$ of FOC. This flux could correspond to 27 \% of the total Particulate Organic Carbon (POC) load exported by the Rhône River to the Mediterranean Sea. At a global scale, our findings suggest that erosion of badlands may contribute significantly to the transfer of FOC from continental surfaces to depositional environments.

Keywords: fossil organic matter, experimental watersheds, organic carbon fluxes, mechanical weathering, chemical weathering.

\section{Introduction}

Continental surfaces are composed of a combination of various sedimentary, metamorphic and plutonic rocks. Sedimentary rocks as shales, carbonates and 
sandstones represent $65 \%$ of the total continental surface (Amiotte-Suchet et al., 2003). All of these rocks contain a variable Fossil Organic Carbon (FOC) content, generally comprised of between 0.01 to near 50.00 wt. $\%$ - with an average of 0.25 to 0.97 wt. \% for carbonates and shales (Ronov and Yaroshevsky, 1976). At outcrop, FOC is generally considered fully mineralized and acts as a $\mathrm{CO}_{2}$ source for the atmosphere (Berner, 1989; Berner and Canfield, 1989; Berner and Maasch, 1996). However, this assumption is in disagreement with numerous observations which suggest a natural resistance and FOC occurrence in various modern carbon reservoirs, including soils (Lichtfouse et al., 1997a, 1997b; Di-Giovanni et al., 1998a, 1999a, 1999b, 2000; Copard et al., 2006; Graz et al., 2010, 2011), rivers (Kao and Liu, 1996; Di-Giovanni et al., 2000; Massiello et al., 2001; Blair et al., 2003, 2004; Raymond and Bauer, 2001, 2004; Copard et al., 2006; Graz et al., 2010, 2011; Hilton et al., 2011) and recent sediments (Combaz, 1980; Tyson, 1995; Di-Giovanni et al., 1997, 1998b, 1999b, 1999c, 2000; Eglinton et al., 1997; Leithold et al., 2001; Blair et al., 2003; Dickens et al., 2004a, 2004b; Wakeham et al., 2004; Galy et al., 2008a, 2008b), which indicates that the FOC is not completely oxidized. However, while the occurrence of FOC in various C-reservoirs is undisputable, the global flux of weathered FOC to the hydrosphere still remains unknown.

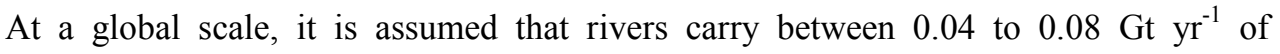
particulate FOC to the world's oceans (Meybeck, 1993, 2005; Blair et al., 2003). This input mainly originates from mechanical weathering of outcropping rocks or soils. Nevertheless, FOC release from the continents can not be directly related to the estimated FOC input to world's ocean, as an unknown fraction of FOC can be partially (Fredericks et al., 1983; Lo and Cardott, 1995; Petsch et al., 2000; Copard et al., 2002) 
or fully mineralised (Berner, 1989; Petsch et al., 2000) during its storage and / or transfer within continental surfaces. Until now, we only know that the modelled FOC delivery due to chemical weathering (chemFOC) of shales and carbonates can reach


originating from chemical weathering of sandstones is supposed negligible (AmiotteSuchet et al., 2003). For these latter fluxes, the lack of global estimate is related to the complex dependence on climatic and geological conditions. These chemFOC and FOC loads to oceans are estimated to be the same order of magnitude of the particulate

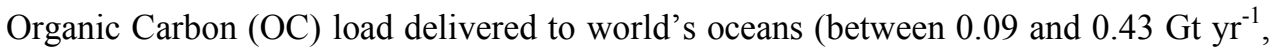
Ittekot, 1988; Degens et al., 1991; Berner, 1992; Meybeck, 1993; Ludwig et al., 1996; Stallard, 1998; Schlunz and Schneider, 2000). Yet, the impact of FOC fluxes remains uncertain.

Here we quantify the flux of FOC due to mechanical and chemical weathering in two small experimental watersheds over annual to decadal timescales. The FOC is attributable to Jurassic marls weathering that contribute to $80 \%$ of the suspended load of the "moyenne Durance"; one of the main tributaries of the Rhône River (Fournier, 2004). A classical geochemical analysis (Rock-Eval 6 pyrolysis) was used to characterize organic matter in studied samples (bedrocks, soil litters and riverine particles). FOC fluxes were estimated by monitoring the particulate (1985-2005 period) and dissolved (year 2002) exports at the outlet of the watersheds.

\section{Material and methods}

\subsection{Study area}


The study area corresponds to two experimental watersheds Laval $\left(0.86 \mathrm{~km}^{2}\right)$ and Moulin $\left(0.08 \mathrm{~km}^{2}\right)$ located near Digne ( $44^{\circ} 08^{\prime} 33^{\prime}$ 'N, $06^{\circ} 22^{\prime}$ 05' 'E ; Alpes-de-HauteProvence, France; Fig. 1) and overlying Callovo-Oxfordian marly limestones (Mathys et al., 2003; Mathys, 2006). Such rocks are very sensitive to weathering and develop typical badlands morphology with $\mathrm{V}$-shapes gullies, producing very high sediment loads ( $>10 \mathrm{~g} / \mathrm{L}$ ) during floods (Mathys et al., 2003). These two experimental watersheds deliver a sediment yield of $5700 \mathrm{t} \mathrm{km}^{-2} \mathrm{yr}^{-1}$ in Moulin and $11200 \mathrm{t} \mathrm{km}^{-2} \mathrm{yr}^{-1}$ in Laval (Mathys et al., 2003) comparable to other badlands located around the Mediterranean Sea (Nadal Romero et al., 2011). These watersheds present different vegetal cover densities: Laval (32\%), and Moulin (46\%) (Mathys et al., 2003).

\subsection{Previous results}

72 watershed samples (bedrock: 5 samples; soils: 15 samples; regolith profiles (bedrocks to soils): 44 samples; riverine particles: 8 samples) were previously examined in order to distinguish fossil and recent organic matter (Copard et al., 2006; Graz et al., 2011). We used complementary techniques: optical (palynofacies methods), geochemical (Rock-Eval 6 pyrolysis, $\mathrm{C} / \mathrm{N}$ ratio), molecular (gas chromatography/mass spectrometry) and isotopic (stable C isotopic composition) analyses. These investigations were completed by quantitative palynofacies analysis performed on 82 samples from Laval watershed (bedrock, regolith profiles, soils: 72 samples; riverine particles: 10 samples, Graz et al., 2010). Fossil and recent organic markers were identified and tracked through the different organic carbon reservoirs. The results permit us to (i) quantify bedrock organic content varying between 0.10 (limestones) and $0.50-0.70$ wt. $\%$ (marls) - such values are of the same order as the average value $(0.50$ 
wt. \%) obtained by Artru (1972) on 6000 callovo-oxfordian marls samples; (ii) distinguish recent and fossil organic matter and highlight the contribution of Fossil Organic Matter (FOM containing FOC), which can be found in all the studied organic carbon reservoirs. FOM contribution to total organic matter varies from 5.5 to $70.0 \%$ in soils, 20.0 to $95.0 \%$ in regolith profiles and 47.0 to $91.0 \%$ in riverine particles (Graz et al., 2010, 2011).

\subsection{Strategy, organic matter characterization and samples design}

Compilation of the data (Copard et al., 2006; Graz et al., 2010, 2011, see section 2.2.) indicates that FOM contribution was only quantified for 18 published riverine samples between years 2002 and 2008. However, this small number of samples is not sufficient to estimate annual FOM (and thus FOC) fluxes at the watersheds outlets. In order to address this issue, a calibration of Rock-Eval 6 parameters using previous quantitative palynofacies results was performed (bedrock, regolith profiles, soils and riverine particles, Graz et al., 2010). The obtained HI / FOM relation was applied to 60 other riverine samples in order to directly distinguish fossil and recent organic carbon (see section 3.1.). These samples were collected by using automatic sampling between 1999 and 2008 at Laval (30 suspended load / 6 bed load) and Moulin (24 suspended load) outlets.

Rock-Eval 6 pyrolysis (RE6, Vinci Technologies ${ }^{\circledR}$ ), a method previously developed for petroleum purposes and the analysis of sedimentary rocks, is now successfully applied for recent material (soils and recent sediments, Di-Giovanni et al., 1997, 1998b; Noël et al., 2001; Disnar et al., 2003; Copard et al., 2006; Sebag et al., 2006). The protocol consists of two successive stages performed under a temperature program of $30^{\circ} \mathrm{C} \mathrm{min}{ }^{-}$ 
1. The former consists of pyrolysis of $100 \mathrm{mg}$ of crushed sample in an oven. Hydrocarbon and oxygenated products released during a temperature increase from 200 to $650{ }^{\circ} \mathrm{C}$ are removed via a $\mathrm{N}_{2}$ flow and quantified with flame ionization and infrared detectors respectively. The second stage consists of oxidation in an oven of the carbonaceous residue subjected to a temperature increase from 400 to $750^{\circ} \mathrm{C}$ (Lafargue et al., 1998). Analysis of the pyrolysis signals provides some classical parameters such as Hydrogen Index (HI, in $\mathrm{mg} \mathrm{HC}^{-1} \mathrm{TOC}$ ), which can be defined as an indicator of the hydrogen richness of the organic matter. The Organic Carbon content (OC) is given by the Total Organic Carbon (TOC, expressed in wt. \%), equal to the sum of pyrolysed OC and residual $\mathrm{OC}$ provided by the oxidation stage.

A first study dealing with the development of quantitative palynofacies was already published (Graz et al., 2010). This method allowed us to determine organic particles mass concentrations and to discriminate Recent Organic Matter (ROM) from Fossil Organic Matter (FOM containing FOC) in 82 samples from Laval watershed (bedrock, regolith profiles, soils: 72 samples; riverine particles: 10 samples). Rock-Eval pyrolysis was also performed for all these samples. HI values (11 to $180 \mathrm{mg} \mathrm{HC} \mathrm{g}^{-1} \mathrm{TOC}$ ) and the relative proportion of ROM (0.0 to $88.0 \%$ ) were used to calibrate Rock Eval parameters in order to obtain fossil and recent carbon proportions in all studied samples (see 3.1.). Results are listed online in supplementary material.

\subsection{Calculation of FOC fluxes released by bedrocks mechanical (mecFOC) and chemical weathering (chemFOC)}

Draix riverine particles are the product of mechanical weathering of the bedrock (Di- 
Giovanni et al., 2000; Copard et al., 2006). mecFOC can be calculated by considering FOC content of bedrocks and their annual fluxes. Such calculations were possible since the studied watersheds were previously equipped by Cemagref in order to estimate both the water discharge and fine and coarse solid transports (see Richard and Mathys, 1999; Mathys et al., 2003; Klotz et al., 2005; Mathys, 2006; for further details). At the outlet of Laval and Moulin catchments, a gauging station, with a calibrated flume is equipped with a series of recorders (e.g. floating device, ultrasonic sensor, radar sensor). Upstream of this flume a sediment trap retains the coarse material. This method gives a total amount of bed load conveyed by the streams. In the gauging flume, an automatic sampler takes samples during floods with a program referring to both the level of water and the time lag between two samples, giving a discontinuous estimation of fine solid transport during a flood. Since 1995, prototypes of optical fiber sensors were installed and provide measures sediment concentration of the flow using back scattering properties of the mixture. As a result, combined sediment concentration and discharge measurements allow one to calculate the suspended sediment yield for flood events and on annual timescales.

The dissolution of rocks that contain carbonates produces dissolved carbonates and an insoluble residue that can contain organic carbon if the parent rocks contained organic matter. If the yield of dissolved carbonates and the initial carbonates content of the parent rocks are known, then the yield of the insoluble residue can be calculated (DiGiovanni et al., 2002). Furthermore, if the initial FOC content in the parent rock is known, then the amount of FOC yielded from the dissolution of the carbonate matrix can be estimated. Calculations were only possible for the year 2002. Indeed, Cras (2005) carried out a multi-scale hydrochemical investigation over one year in Laval and 
Moulin catchments, including both high flow and low flow periods. Automatic water samplers were used to collect water during the high flows periods whereas low flow waters were hand sampled. According to the flood events, the sampling frequency could reach 5 min. During low flow periods, a weekly sampling was carried out. Mean concentration estimates were calculated from 163 and 208 samples in Laval (including 6 flood events) and in Moulin (including 6 flood events) respectively. Cras et al (2007) showed that rainfall did not contain significant amount of $\mathrm{Ca}^{2+}$. Accordingly, we can consider that $\mathrm{Ca}^{2+}$ measured at the outlet of the watersheds mainly originated from bedrock chemical weathering.

\section{Results}

\subsection{Rock-Eval 6 pyrolysis parameters calibration}

There is a significant correlation between previously determined proportions of ROM (Recent Organic Matter - by opposition to FOM - Graz et al., 2010) and HI values from Rock-Eval pyrolysis $\left(\mathrm{R}^{2}=0.93\right.$, Fig. 2) for 82 samples from Laval watershed (bedrock, regolith, soil and riverine particles, see online supplementary material for more details). Accordingly, a relationship between $\mathrm{HI}$ values and ROM \% can be defined and lead to the quantification of FOM \% (FOM \% $=100-\mathrm{ROM} \%)$ in riverine suspended sediments following the equation (Eq.1):

(Eq 1) HI $\left(m g\right.$ HC.g ${ }^{-1}$ TOC $)=1.7927 \times$ ROM $(\%)+10.292$ 
Uncertainties on $\mathrm{HI}$ values (5\%) are widely lower than those on palynofacies results (15 $\%$, Graz et al., 2010). Uncertainties on calculated FOM \% values are then close to $15 \%$.

\subsection{FOC content of riverine particles}

Riverine particles present low TOC and HI values ( 0.46 to $0.65 \%$ and 19 to $72 \mathrm{mg} \mathrm{HC}$ $\mathrm{g}^{-1}$ TOC respectively, Tables 1 and 2) that are similar, but slightly higher, to those observed in bedrocks samples (Graz et al., 2010).

The observed relationship between HI values and ROM \% (Fig. 2) permits to estimate FOC and Recent Organic Carbon (ROC) contents (wt. \%) (FOC = TOC x FOM \%; and ROC $=$ TOC $\times$ ROM \%) in all studied riverine samples (Laval, Table 1 and Moulin, Table 2). FOC content appears constant in all studied samples and close to $0.5 \mathrm{wt} . \%(+/$ $0.07,60$ samples). This is in agreement with previous results (18 samples) showing that riverine particles of these watersheds are the direct product of bedrocks mechanical weathering (Di-Giovanni et al., 2000; Copard et al., 2006; Graz et al., 2010).

The higher ROC values (from 0.1 to 0.2 wt. \%) are obtained for Moulin suspended load samples, which also exhibits a large area of vegetation cover (46\%, Mathys et al., 2003). The lower ones $(<0.1 \%)$ are obtained for Laval suspended load samples, where the vegetal cover area is somewhat lower (32\%, Mathys et al., 2003).

\subsection{FOC fluxes released by bedrocks mechanical weathering}

Measurements of solid export values at the outlets (Klotz et al., 2005; Mathys, 2006) are highly variable from one year to another but also from one basin to another (Table 3). The export loads at Laval outlet range from $4352-21148 \mathrm{t} \mathrm{km}^{-2} \mathrm{yr}^{-1}$ compared to 
$1350-9990 \mathrm{t} \mathrm{km}^{-2} \mathrm{yr}^{-1}$ at Moulin outlet. With respect to the spatial scale (area) and badlands context, these magnitudes are comparable to those observed for numerous badlands area, located around the Mediterranean Sea (Nadal-Romeo et al., 2011).

Considering that the FOC content of these loads is close to $0.5 \mathrm{wt}$ \% (Tables 1 and 2, see also section 3.2.), mecFOC can be calculated. Obtained values range between 22 and $106 \mathrm{t} \mathrm{km}^{-2} \mathrm{yr}^{-1}$ for Laval, and between 7 and $50 \mathrm{t} \mathrm{km}^{-2} \mathrm{yr}^{-1}$ for Moulin (Table 3). The inter-annual FOC fluxes average 59 and $30 \mathrm{t} \mathrm{km}^{-2} \mathrm{yr}^{-1}$ respectively.

\subsection{FOC fluxes release by bedrocks chemical weathering}

Exported total dissolved load were 340 and $570 \mathrm{t} \mathrm{km}^{-2}$ for the year 2002 respectively for Laval and Moulin (Table 4; Cras, 2005). Total Dissolved Solid (TDS) concentrations reached an average of 13.4 and $11.7 \mathrm{mmol}^{-1}$ respectively in watershed waters and $\mathrm{Ca}^{2+}$ concentrations reached 2.5 and $2.4 \mathrm{mmol}^{-1}$ (Table 4).

$\mathrm{Ca}^{2+}$ concentrations measured at the outlets of watersheds originate from the bedrocks carbonate dissolution as rainwater does not contain $\mathrm{Ca}^{2+}$ (Cras et al., 2007). This dissolution is illustrated by the following equation (Eq.2):

$$
\text { (Eq.2) } \mathrm{CaCO}_{3}+\mathrm{CO}_{2}+\mathrm{H}_{2} \mathrm{O} \Leftrightarrow \mathrm{Ca}^{2+}+2 \mathrm{HCO}_{3}^{-}
$$

On this basis, the estimation of the chemical weathered bedrock mass $\left(\mathrm{t} \mathrm{km}^{-2} \mathrm{yr}^{-1}\right)$ can be obtained following three steps (Eqs.3, 4 and 5).

\footnotetext{
(Eq.3) Annual $\mathrm{Ca}^{2+}$ fluxes $\left(\mathrm{t} \mathrm{km}^{-2} \mathrm{yr}^{-1}\right)=\mathrm{M} \mathrm{Ca}^{2+} \%$
} 
Where $\mathrm{M}$ is dissolved load exported from the watersheds in 2002 (Table 4) and $\mathrm{Ca} \%$ is the $\mathrm{Ca}^{2+}$ content in TDS from riverine waters (18.7 and 20.5 for Laval and Moulin respectively).

(Eq.4) Annual mass of dissolved $\mathrm{CaCO}_{3}\left(\mathrm{t} \mathrm{km}^{-2} \mathrm{yr}^{-1}\right)=$ annual $\mathrm{Ca}^{2+}$ fluxes $\mathrm{x} 2.5$

Where 2.5 correspond to the molar mass of $\mathrm{Ca}$ reported to the molar mass of $\mathrm{CaCO}_{3}$ $(100 / 40)$.

(Eq.5)

Mass of altered bedrock $\left(\mathrm{t} \mathrm{km}^{-2} \mathrm{yr}^{-1}\right)=$ Annual mass of dissolved $\mathrm{CaCO}_{3} \times(100 / \mathrm{Tc})$

Where $\mathrm{Tc}$ is the $\mathrm{CaCO}_{3}$ content of watersheds bedrocks (i.e. $35 \%$, Simmonet et al., 1995).

Considering the bedrocks average TOC (0.50 wt. \%, Artru, 1972; Graz et al., 2010) and the annual mass of altered bedrocks, chemFOC $\left(\mathrm{t} \mathrm{km}^{-2} \mathrm{yr}^{-1}\right)$ can be calculated as follows:

(Eq.6) chemFOC $\left(\mathrm{t} \mathrm{km}^{-2} \mathrm{yr}^{-1}\right)=$ Mass of altered bedrock $\left(\mathrm{t} \mathrm{km}^{-2} \mathrm{yr}^{-1}\right) \mathbf{x}$ bedrock TOC $(0.50$ wt. \%)

FOC fluxes inherited from chemical weathering of bedrocks (chemFOC) can be further mineralized, dissolved or stored as a insoluble residue. They reach 2.2 and $4.2 \mathrm{t} \mathrm{km}^{-2} \mathrm{yr}^{-}$ ${ }^{1}$ for Laval and Moulin watersheds, respectively.

\section{Discussion}




\subsection{FOC fluxes}

For these watersheds, FOC input in continental surfaces is mainly controlled by mechanical weathering (average mecFOC from 30 to $59 \mathrm{t} \mathrm{km}^{-2} \mathrm{yr}^{-1}$, Table 3) while chemFOC fluxes, inherited from chemical weathering of bedrocks and considered as an insoluble residue, are much lower (from 2 to $4 \mathrm{t} \mathrm{km}^{-2} \mathrm{yr}^{-1}$, year 2002). This strong difference between mechanical and chemical FOC estimates is not a surprise with respect to the geomorphological context (badlands) of these watersheds, marked by predominant gully erosion.

However in our study, the estimated chemFOC fluxes in Moulin catchment $\left(4.2 \mathrm{t} \mathrm{km}^{-2}\right.$ $\left.\mathrm{yr}^{-1}\right)$ are twice that of Laval catchment $\left(2.2 \mathrm{t} \mathrm{km}^{-2} \mathrm{yr}^{-1}\right)$. This suggests that chemical weathering is more efficient within the former catchment. One of the possible causes to explain this variation would be the higher extent of forest area in Moulin (46\%) than in Laval (32\%, Mathys et al., 2003. Indeed, it is well known that a large area of forest cover leads to a decrease in the runoff intensity (e.g. Campy and Macaire, 2003). Such context would favor the storage of FOC as an insoluble residue; which can be stored and subsequently mineralized in regoliths or soils or even exported if a future mechanical weathering occurs prior to its mineralization. mecFOC fluxes are globally twice higher for Laval $\left(59 \mathrm{t} \mathrm{km}^{-2} \mathrm{yr}^{-1}\right)$ than for Moulin $\left(30 \mathrm{t} \mathrm{km}^{-2} \mathrm{yr}^{-1}\right)$ catchments. Again, a possible cause for this variation is the lower forest cover in Laval catchment (32\%). This could also exacerbated by the higher mean slope values observed for Laval (58\%, Mathys et al., 2003), which should inhibit the development of forest cover and promote the mechanical weathering via an efficient runoff and erosion processes (Dietrich et al., 2003). 
mecFOC yields from the studied catchments are of the same order of magnitude as FOC yields previously reported in suspended sediments from tectonically active mountain catchments in USA/California $\left(9 \mathrm{t} \mathrm{km}^{-2} \mathrm{yr}^{-1}\right.$ Eel river, Blair et al., 2003; Leithold et al., 2006; $11 \mathrm{t} \mathrm{km}^{-2} \mathrm{yr}^{-1}$ Santa Clara river, Blair et al., 2003; Komada et al., 2004), New Zealand $\left(14 \mathrm{t} \mathrm{km}^{-2} \mathrm{yr}^{-1}\right.$ Southern Alpines rivers, Hilton et al., 2008; $29 \mathrm{t} \mathrm{km}^{-2} \mathrm{yr}^{-1}$ Waipaoa river, Gomez et al., 2003; Leithold et al., 2006) and Taiwan (19 $\mathrm{t} \mathrm{km}^{-2} \mathrm{yr}^{-1}$, Lanyang Hsi, Kao and Liu, 1996, from 12 to $246 \mathrm{t} \mathrm{km}^{-2} \mathrm{yr}^{-1}$, Hilton et al., 2011). Our results suggest that high mecFOC transfers in particulate load are not restricted to tectonically active mountains belts. Steep terrain and weak sedimentary rocks give rise to the high calculated yields herein. As such, the delivery of FOC to depositional setting may be more widespread than previously thought (e.g. Blair et al., 2003; Hilton et al., 2011).

\subsection{Fate of FOC in continental surfaces}

The riverine particles at outlets of these watersheds reach the Rhône delta in less than five days (IRS, 2001). This suggests a very short transit time and little storage of FOC within the Durance and the Rhone catchments, which can be considered as a conduit for transporting FOC to the Mediterranean Sea. Consequently FOC delivered by mechanical weathering could significantly contribute to Rhône rivers organic content. Considering that, (i) at a regional scale (Durance catchment), watershed badlands outcrops area, where erosion of FOC is likely, reach $233 \mathrm{~km}^{2}$ (Brochot, 1999; Rey et al., 2007), (ii) all of these badlands present a similar erosion rate (Saignon and Savournon watersheds, Olivry and Hoorelbeck, 1990; Rey, 2002; Ray et al., 2002) which are also comparable to other badlands area located around the Mediterranean sea 
(Nadal Romero et al., 2011) and (iii) the average mecFOC we obtained is $52 \mathrm{t} \mathrm{km}^{-2} \mathrm{yr}^{-1}$, such formations covering at best $0.25 \%$ of the Rhône watershed $\left(97800 \mathrm{~km}^{2}\right)$, could likely deliver $12000 \mathrm{t} \mathrm{yr}^{-1}$ of FOC to the Mediterranean Sea. This flux could correspond to 27 \% of the total particulate organic carbon annually delivered by the Rhône river (44 $080 \mathrm{t} \mathrm{yr}^{-1}$, Ludwig et al., 1996). This C-kerogen (FOC) has been recorded in marine sediments of Gulf of Lion (Gadel and Ragot, 1973) that are likely fed by Rhone sediments (Cauwet et al., 1990). Such FOC reburial in marine sediments suggests the balance between $\mathrm{OC}$ burial and FOC oxidation maintaining atmospheric $\mathrm{O}_{2}$ constant (Berner, 1989; Berner and Canfield, 1989) is not completed (Hilton et al., 2011). This also means that $\mathrm{O}$ and $\mathrm{C}$ cycles should be revisited in the light of this FOC route for which a significant part, strongly controlled by the chemical and physical properties of kerogen (Copard et al., 2007; Galy et al., 2008b), may be reburied (e.g. Hilton et al., 2011).

FOC delivered by chemical dissolution of bedrocks with carbonate matrix (e.g. marls) can be mineralized, dissolved or stored in regoliths and soils. Its resident time in soils could be close to $10^{4}$ years (Keller and Bacon, 1998; Petsch et al., 2000). However this duration is purely theoretic and should be considered with care as the mineralization rate firstly depends on chemical and physical properties of FOC. On the whole, the recalcitrant character of FOC increases with the richness of $\mathrm{C}$ content associated to $\mathrm{H}$ depleted content of kerogen (Joseph and Oberlin, 1983). This implies that higher burial temperature of kerogen produces material more recalcitrant to chemical weathering as oxidation, hydrolysis or biodegradation. In other terms, a mature kerogen reaching the gas window (close to the methagenesis, Durand, 1980) as metha-anthracites or the ultimate C-member, graphite, could be persistent over a long period in continental 
surfaces and can be exported to oceans (Galy et al., 2008b; Bouchez et al., 2010). For some lower degree of thermal evolution, kerogen resistance toward weathering is governed by its chemical composition inherited from the biological precursors and previous processes experienced before burial. Accordingly, a kerogen showing a lignocellulosic origin (type III in a Van Krevelen diagram) with a high proportion of aromatic sheets, exhibits a higher resistance toward weathering than a kerogen consisting in bacterial and/or algale origin (type I and II in a Van Krevelen diagram) with rather a higher proportion of aliphatic compounds likely to be preferentially attacked by oxidation (Copard, 2002 and references therein). However analysis of soil OM modulates this simplistic postulate where some rich-aliphatic compounds appear to be highly resistant towards soil processes (e.g. Lichtfouse et al., 1998). As some field examples, mineralization rates of FOC of outcropping humic coals ranged from different ranks (from low to high volatile bituminous coals) are comprised between 20 to 45\% (Fredericks et al., 1983; Lo and Cardott, 1995; Copard et al., 2002) while Ckerogen of outcropping black shales (phytoplanctonic-derived origin) present a complete mineralization (Petsch et al., 2000). For the FOM disseminated in outcropping marls of the Draix experimental catchments, FOM is dominantly a type III kerogen (Graz et al., 2010, 2011). During Jurassic, these marls were deposited in marine environments where a mixture between marine and continental organic matter classically occurs (Artru, 1972). Without any further alterations, and regarding the maturity level reached by the kerogen disseminated in these rocks during burial (attested by a low Tmax values, $<410^{\circ} \mathrm{C}$, from the RE6 pyrolysis, Copard et al., 2006; Graz et al., 2011), this kerogen would have exhibited some HI values higher than 400 mg HC g-1 TOC (Espitalié et al., 1985). However, for the examined rocks, HI values 
never exceed $180 \mathrm{mg} \mathrm{HC} \mathrm{g}^{-1} \mathrm{TOC}$ and highlight that this kerogen is already weathered. This means that the kerogen has already lost a significant (but unknown) amount of labile FOC prior analyses, during a chemical weathering as the weathering front can dip several meters from the soil surface (e.g. Petsch et al., 2000). This kerogen, or more precisely this recalcitrant "residual kerogen", is thus resistant against further weathering. This could explain why the observed mineralization rates of FOC along some previously studied regolith profiles in these catchments never exceed $30 \%$ (Graz et al., 2011). As a consequence, a significant part of FOC released by chemical weathering of bedrocks can be stored in regoliths.

Unfortunately, constraint on the chemical composition of kerogen is not sufficient to predict its persistence in continental surfaces. External factors of climate, geological context and more recently of Human disturbances (e.g. Land Use Change on forest cover) in continental surfaces advance or mitigate the mineralization rate. As an example the aggressiveness of climate, both temperatures than precipitations amount as seen in tropical climate, would improve the mineralization rate of any OM including kerogen with a higher biodegradation or oxidation processes. If this FOC escapes from such processes, soil can be further eroded and deliver its FOC to rivers as part of the particulate load.

\section{Conclusions}

This study proposes a first assessment of FOC fluxes release by mechanical and chemical weathering of marls in badlands. With values ranging from 30 to $59 \mathrm{t} \mathrm{km}^{-2} \mathrm{yr}^{-}$ 1 , fluxes due to mechanical weathering are predominant and are the same order of 
magnitude than those previously estimated from tectonically active mountain catchments ( 9 to $246 \mathrm{t} \mathrm{km}^{-2} \mathrm{yr}^{-1}$ ). These significant values are not surprising in badlands due to weak substrate and high local slop in gully valleys which drive high physical erosion rates. At the scale of the lower course of the Rhone river, we assume that such geological formations could annually export $12000 \mathrm{t}$ of FOC into the Mediterranean Sea. At global scale, rivers draining such badlands, whose lithology is mainly composed of marls and clayed rocks (Nadal Romero et al., 2011) rich in organic carbon, could be also a significant source of FOC in continental surfaces. This FOC can be conveyed downstream of the river with the clastic load to ocean sediments with implications for the global C and O biogeochemical cycles (Berner 1989; Blair et al., 2003).

FOC fluxes caused by the chemical dissolution of the bedrock during weathering are lower and reach respectively 2.2 and $4.2 \mathrm{t} \mathrm{km}^{-2} \mathrm{yr}^{-1}$ for Laval and Moulin watersheds. Despite a high resistance of this FOC against weathering, this could promote storage as insoluble residues (soils, regoliths), and a part of this carbon can either be mineralized or dissolved.

At global scale, the fate of FOC depends on several parameters as the physical and chemical properties of FOC (origin, temperature recorded during OM burial), the duration of exposure to weathering, but also on the nature and hence the aggressiveness of the weathering processes (e.g. hydrolysis, bacterial activity).

Our results confirm that the release of FOC by mechanical and chemical weathering of sedimentary rocks does not simply act as a source of $\mathrm{C}$ to the atmosphere, but can also supply other carbon reservoirs (soils, riverine particles, sediments). Fossil contribution should be taken into account by other studies based on organic matter data and the role of FOC in the carbon cycle has to be revisited. 


\section{Acknowledgements}

This work is a contribution of the GIS "Bassins de Draix, étude de l'érosion en montagne" piloted by the CEMAGREF and was financially supported by the CNRS program INSU PNSE-ACI 2001: "Influence de l'érosion sur les flux de matière organique fossile dans les géosystèmes continentaux actuels (sols, cours d'eau) : bassins expérimentaux de Draix, Alpes de Haute Provence, France". Authors thank Marielle Hatton, Emily Moore and Jean-Emmanuel Olivier for their technical / analytical supports and corrections. They also warmly thank Prof. Lane and Robert Hilton for their constructive comments.

\section{References}

Amiotte-Suchet P, Probst JL, Ludwig W. 2003. Worldwide distribution of continental rock lithology: implications for the atmospheric/soil $\mathrm{CO} 2$ uptake by continental weathering and alkalinity river transport to the oceans Global Biogeochemichal Cycles 17: DOI: 10.1029/2002GB001891.

Artru P, 1972. Les terres noires du basin rhodanien (Bajocien supérieur à oxfordien moyen) : stratigraphie, sédimentologie, géochimie. Doctoral thesis, Lyon University Grenoble, $182 \mathrm{pp}$.

Berner RA. 1989. Biogeochemical cycles of carbon and sulphur and their effect on atmospheric oxygen over Phanerozoic time. Paleogeography Paleoclimatolology Paleoecology 75: 97-122.

Berner RA, Canfield DE. 1989. A new model for atmospheric oxygen over phanerozoic time. American Journal of Science 289: 333-361. 
Berner RA. 1992. Comments on the role of marine of marine sediment burial as a repository for anthropogenic $\mathrm{CO}_{2}$. Global Biogeochemichal Cycles 6: 1-2.

Berner RA, Maasch KA. 1996. Chemical weathering and controls on atmospheric $\mathrm{O}_{2}$ and $\mathrm{CO}_{2}$ : Fundamental principles were enunciated by J.J. Ebelmen in 1845 . Geochimica and Cosmochimica Acta 60: 1633-1637.

Blair NE, Leithold EL, Ford ST, Peeler KA, Holmes JC, Perkey DW. 2003. The persistence of memory: The fate of ancient sedimentary organic carbon in a modern sedimentary system. Geochimica and Cosmochimica Acta 67: 63-73.

Blair NE, Leithold RL, Aller RC. 2004. From bedrock to burial: the evolution of particulate organic carbon across coupled watershed-continental margin systems. Marine Chemistry 92: 141-156.

Bouchez J, Beyssac O, Galy V, Gaillardet J, France-Lanord C, Maurice L, MoreiraTurcq P. 2010. Oxidation of petrogenic organic carbon in the Amazon floodplain as a source of atmospheric $\mathrm{CO}_{2}$, Geology 38: doi:10.1130/G30608.1.

Brochot S. 1999. Les bassins versants de Draix, expérimentaux... et représentatifs. Les bassins versants expérimentaux de Draix laboratoire d'étude de l'érosion en montagne - actes du séminaire, Draix, Le Brusquet, Digne. Cemagref Editions, Antony : 223-234.

Campy M, Macaire JJ. 2003. Géologie de la surface. Erosion, transfert et stockage dans les environnements continentaux, second Ed. Dunod, Paris, 440 p. 
Cauwet G, Gadel F, Sierra MMD, Donard O, Ewald M. 1990. Contribution of the Rhone river to organic-carbon inputs to the Northwestern Mediterranean sea. Continental Shelf Research $10: 1025-1037$.

Combaz A. 1980. Les kérogènes vus au microscope. In Kerogen. Insoluble Matter from Sedimentary Rocks, Durand B (ed). Technip: Paris; 56-112.

Copard Y. 2002. Altération diagénétique et post-diagénétique (thermicité et oxydation) des charbons carbonifères du Massif Central français (Saint-Etienne, Graissessac et autres lieux). Doctoral thesis, University of Orléans, 245pp.

Copard Y, Disnar JR, Becq-Giraudon JF. 2002. Erroneous maturity assessment given by Tmax and HI Rock-Eval parameters on highly mature weathered coals. International Journal of Coal Geology 49: 57-65.

Copard Y, Di-Giovanni C, Martaud T, Albéric P, Olivier JE. 2006. Using Rock-Eval 6 pyrolysis for tracking fossil organic carbon in modern environments: implications for the roles of erosion and weathering. Earth Surface Processes and Landforms 31: 135153.

Copard Y, Amiotte-Suchet P, Di-Giovanni C. 2007. Storage and release of fossil organic carbon related to weathering of sedimentary rocks. Earth and Planetary Science Letters 258: 345-357.

Cras A. 2005. Etude de la dynamique de fonctionnement hydrologique des bassins versants torrentiels marneux. Apport du traçage naturel. Doctoral thesis, Université d'Avignon et des pays de Vaucluse (France), 161pp.

Cras A, Marc V, Travi Y. 2007. Hydrological behaviour of sub-Mediterranean alpine headwater streams in a badlands environment. Journal of Hydrology 339: 130-144. doi: 10.1016/j.jhydrol.2007.03.004 
Degens ET, Kempe S, Richey JE. 1991. Biogeochemistry of major world rivers. SCOPE 42: 323-344.

Dickens AF, Gélinas Y, Hedges JI. 2004a. Physical separation of combustion and rock sources of graphitic black carbon in sediments. Marine Chemistry 92: 215-223.

Dickens AF, Gélinas Y, Hedges JI. 2004b. Reburial of fossil organic carbon in marine sediments. Nature 427 : 336-339.

Dietrich WE, Bellugi DG, Sklar LS, Stock JD, Heimsath AM, Roering JJ. 2003. Geomorphic transport laws for predicting landscape form and dynamics prediction in geomorphology. Prediction in geomorphology, Geophysicam Monograph 135: doi: 10.1029/135GM09.

Di-Giovanni C, Bertrand Ph, Campy M, Disnar JR. 1997. Contribution de matière organique méso-cénozoïque dans un flux organique terrigène tardi et post-glaciaire (bassin de Chaillexon, Doubs, France). Bulletin de la Société géologique de France $168: 553-559$.

Di-Giovanni C, Disnar JR, Bichet V, Campy M. 1998a. Sur la présence de matière organique méso-cénozoïque dans les humus actuels (bassin de Chaillexon, Doubs, France). Comptes rendus de l'Académie des Sciences Paris 326 : 553-559.

Di-Giovanni C, Disnar JR, Bichet V, Campy M, Guillet B. 1998b. Geochemichal characterization of soil organic matter and variability of a past glacial detrital organic supply (Chaillexon lake, France). Earth Surface Processes and Landforms 23: 10571069.

Di-Giovanni C, Disnar JR, Campy M, Macaire JJ. 1999a. Variability of the ancient organic supply in modern humus. Analusis 27: 398-402. 
Di-Giovanni C, Disnar JR, Turpin S, Bréheret JG. 1999b. Estimation de la contribution des matières organiques remaniées au stock organique des sols et sédiments lacustres (bassin des Peyssiers, hautes Alpes, France). Bulletin de la Société géologique de France $170: 121-129$.

Di-Giovanni C, Disnar JR, Campy M. 1999c. Des particules charbonneuses, témoins des variations de l'érosion chimique d'un bassin versant calcaire durant l'Holocène (bassin de Chaillexon, Doubs, France). Comptes rendus de l'Académie des Sciences Paris $328: 167-172$.

Di-Giovanni C, Disnar JR, Bakyono JP, Keravis D, Millet F, Olivier JE. 2000. Application de l'étude de la matière organique à l'analyse de l'érosion : exemple du bassin versant du Moulin, dans les terres noires des Alpes de Haute Provence, France. Comptes rendus de l'Académie des Sciences Paris 331: 7-14.

Di-Giovanni C, Disnar JR, Macaire JJ. 2002. Estimation of the annual yield of organic carbon released from carbonates and shales by chemichal weathering. Global and Planetary Change 32: 327-343.

Disnar JR, Guillet B, Keravis D, Di-Giovanni C, Sebag D. 2003. Soil organic matter (SOM) characterization by Rock-Eval pyrolysis : scope and limitations. Organic Geochemistry $34:$ 327-343.

Durand, B. 1980. Kerogen: insoluble organic matter from sedimentary rocks. Technips, Paris, $525 \mathrm{pp}$.

Eglinton TI, Benitez-Nelson BC, Pearson A, McNichol AP, Bauer JE, Druffel ERM. 1997. Variability in Radiocarbon Ages of Individual Organic Compounds from Marine Sediments. Science 277, DOI: 10.1126/science.277.5327.796. 
Espitalié J, Deroo G, Marquis F. 1985. La pyrolyse Rock-Eval et ses applications, Partie 1-2. Revue de l'Institut Français du Pétrole 40: 563-579.

Fournier L. 2004. Modélisation de la production des apports sédimentaires dans le bassin versant de la Durance. Master thesis, Université Paris XI, 50 pp.

Fredericks PM, Warbrooke P, Wilson MA. 1983. Chemical changes during natural oxidation of high volatile bituminous coal. Organic Geochemistry 5: 89-97.

Gadel F, Ragot JP. 1973. Sur l'allochtonie de la fraction organique particulaire des dépôts quaternaires récents du Golfe du Lion. In Tissot B, Bienner F (Eds). Adv. Org. Geochem. 21. Technips, Paris; 619-628.

Galy V, France-Lanord C, Lartiges B. 2008a. Loading and fate of particulate organic carbon from the Himalaya to the Ganga-Brahmaputra delta. Geochimica et Cosmochimica Acta, 72: 1767-1787.

Galy V, Beyssac O, France-Lanord C, Eglinton T. 2008b. Recycling of Graphite During Himalayan Erosion: A Geological Stabilization of Carbon in the Crust. Science 7 322: 943-945. DOI: 10.1126/science.1161408.

Gomez B, Trustrum NA, Hicks DM, Rogers KM, Page MJ, Tate KR. 2003. Production, storage, and output of particulate organic carbon: Waipaoa River basin, New Zealand, Water Resource Research 39: doi:10.1029/2002WR001619.

Graz Y, Di-Giovanni C, Copard Y, Laggoun-Defarge F, Boussafir M, Lallier-Verges E, Baillif P, Perdereau L, Simonneau A. 2010. Quantitative palynofacies analysis as a new tool to study transfers of fossil organic matter in recent terrestrial environments. International Journal of Coal Geology 84: 49-62.

Graz Y, Di-Giovanni C, Copard Y, Elie M, Faure P, Laggoun-Défarge F, Lévèque J, Michels R, Olivier J.E. 2011. Occurrence of fossil organic matter in modern 
environments: optical, geochemical and isotopic evidence. Applied Geochemistry 26: $1302-1314$.

Hilton RG, Galy A, Hovius N. 2008. Riverine particulate organic carbon from an active mountain belt: Importance of landslides. Global Biogeochemichal Cycles 22: GB1017, doi:10.1029/2006GB002905.

Hilton RG, Galy A, Hovius N, Homg M J, Chen H. 2011. Efficient transport of fossil organic carbon to the ocean by steep mountain rivers: An orogenic carbon sequestration mechanism. Geology 39: 71-74.

IRS 2001. Etude globale pour une stratégie de réduction des risques dus aux crues du Rhône. Institution interdépartementale des bassins Rhône-Saône (Ed)., Valence; 40pp.

Ittekot V. 1988. Global trends in the nature of organic matter in river suspensions. Nature 332: 436-438.

Joseph D, Oberlin A. 1983. Oxidation of carbonaceous matter - I Elemental analysis (C, H, O) and IR spectrometry. Carbon 21, 6: 559-564.

Kao SJ, Liu KK. 1996. Particulate organic carbon export from a subtropical mountainous river (Lanyang Hsi), in Taiwan. Limnology and Oceanography 41: 1749-1757.

Keller C K. and Bacon D H.,1998. Soil respiration and georespiration distinguished by transport analyses of vadose $\mathrm{CO}_{2},{ }_{13} \mathrm{CO}_{2}$, and ${ }_{14} \mathrm{CO}_{2}$. Global biogeochemical cycles 12: $361-372$.

Klotz S, Mathys N, Olivier JE. 2005. Annuaire de l'ORE Draix 2005. Document Cemagref (Ed)., France; 34pp. 
Komada T, Druffel ERM, Trumbore SE. 2004. Oceanic export of relict carbon by small mountainous rivers. Geophysichal Research Letters 31: L07504, doi:10.1029/2004GL019512

Lafargue, E, Marquis F, Pillot D. 1998. Rock-Eval 6 applications in hydrocarbon exploration, production and soil contamination studies. Revue de l'Institut Français du Pétrole 53: 421-437.

Leithold EL, Blair NE. 2001. Watershed control on the carbon loading of marine sedimentary particles. Geochimicha and Cosmochima Acta 65: 2231-2240.

Leithold EL, Blair NE, Perkey DW. 2006. Geomorphologic controls on the age of particulate organic carbon from small mountainous and upland rivers. Global Biogeochemichal Cycles 20: GB3022, doi:10.1029/2005GB002677.

Lichtfouse E, Bardoux G. Mariotti A, Balesdent J, Ballentine DC, Mack SA. 1997a. Molecular ${ }^{13} \mathrm{C}$ and ${ }^{14} \mathrm{C}$ evidence for the allochtonous and ancient origin of $\mathrm{C} 16-\mathrm{C} 18$ n-halkanes in modern soils. Geochimica and Cosmochimicha Acta 61: 1891-1898.

Lichtfouse E, Budzinski E, Garrigues P, Eglinton TI. 1997b. Ancient polycyclic aromatic hydrocarbons in modern soils: ${ }^{13} \mathrm{C},{ }^{14} \mathrm{C}$ and biomarkers evidence. Organic Geochemistry 26: 353-359.

Lichtfouse E, Chenu C, Baudin F, Leblond C, Da Silva M, Behar F, Derenne S, Largeau C, Wehrung, P, Albrecht P. 1998. A novel pathway of soil organic matter formation by selective preservation of resistant straight-chain biopolymers: chemical and isotope evidence. Organic Geochemistry 28, 411-415.

Lo HB, Cardott BJ. 1995. Detection of natural weathering of Upper Mc Alester and Woodford shale, Oklahoma. Organic Geochemistry 22: 73-83. 
Lopez Saez J, Corona C, Stoffel M, Rovéra G, Astrade L, Berger F. 2011. Mapping of erosion rates in marly badlands based on a coupling of anatomical changes in exposed roots with slope maps derived from LiDAR data. Earth Surface Processes and Landforms 36, 1162-1171.

Ludwig W, Probst JL, Kempe S. 1996. Predicting the oceanic input of organic carbon by continental erosion. Global Biogeochemichal Cycles 10: 23-41.

Mathys N, Brochot S, Meunier M, Richard D. 2003. Erosion quantification in the small marly experimental catchments of Draix (Alpes de Haute Provence, France).Calibration of the ETC rainfall-runoff-erosion model. CATENA 50: 527548.

Mathys N. 2006. Analyse et modélisation à différentes échelles des mécanismes d'érosion et de transport de matériaux solides. Cas des petits bassins versants de montagne sur marnes (Draix, Alpes de Haute Provence). Doctoral thesis, Institut national polytechnique de Grenoble, $346 \mathrm{pp}$.

Masiello CA, Druffel ERM. 2001. Carbon Isotope Geochemistry of the Santa Clara River. Global Biogeochemichal Cycles 15: 407-416.

Meybeck M. 1993. Riverine transport of atmospheric carbon: sources, global typology and budget. Water, Air, and Soil Pollution 70: 443-463.

Meybeck M. 2005. Origins and behaviours of carbon species in world rivers. In: Roose and Lal (Eds). Erosion and Carbon Dynamics, Advances in Soil Sciences Series. CRC Boca Raton; 209-238.

Nadal-Romero E, Martínez-Murillo J-F., Vanmaercke M., Poesen J, 2011. Scaledependency of sediment yield from badland areas in Mediterranean environments Progress in Physical Geography Progress in Physical Geography ; 1-36. 
Noël H, Garbolino E, Brauer A, Lallier-Vergès E, de Beaulieu JL, Disnar JR. 2001. Human impact and soil erosion during the last 5000 yrs as recorded in lacustrine sedimentary organic matter at Lac d'Annecy, the French Alps. Journal of Paleolimnology 25: 229-244.

Olivry JC, Hoorelbeck J.1990. Erodabilité des terres noires de la vallée du Buëch (France, Alpes du Sud). Cah. ORSTOM, ser. Pédot. XXV; 95-110

Petsch ST, Berner RA, Eglinton TI. 2000. A field study of the chemical weathering of ancient sedimentary organic matter. Organic Geochemistry 31: 475-487.

Raymond PA, Bauer JE. 2001. Riverine export of aged terrestrial organic matter to the North Atlantic Ocean. Nature 409: 497-500.

Raymond PA, Bauer JE. 2004. Controls on the variability of organic matter and dissolved inorganic carbon ages in northeast US rivers. Marine Chemistry 92: 353366.

Rey F. 2002. Influence de la distribution spatiale de la végétation sur la production sédimentaire de ravines marneuses dans les Alpes du sud. Doctoral thesis, Université de Grenoble I, 194 pp.

Rey F, Robert Y, Vento O, 2002. Influence de la végétation forestière sur la formation de dépôts sédimentaires en terrain marneux. Géomorphologie : relief, processus, environnement, $1: 85-92$.

Rey F, Abraham A, Gallicher-Lavanne C, Burylo M, Eugène RE, Mermin E, Puech C. 2007. Etude de la faisabilité d'une opération de réhabilitation écologique de ravines marneuses érodées pour la rétention durable des sédiments à l'échelle du bassin versant de la Durance. Cemagref (Ed). Rapport d'étude de l'Action 8 « Expérimenter le contrôle de l'érosion des versants de marnes noires »du Plan Durance MultiUsages, $51 \mathrm{pp}$. 
Richard D, Mathys N. 1999. History, technical and scientific context of the experimental basins of Draix. Characteristics, avalaible data and main results after ten years of monitoring. Document Cemagref (Ed)., France; 20 pp. http://excerpts.numilog.com/books/9782853625142.pdf

Ronov AB, Yaroshevsky AA. 1976. A new model for the chemical structure of the Earth crust. Geochemistry International 13: 1761-1795.

Schlunz B, Schneider RR. 2000. Transport of terrestrial organic carbon to the oceans by rivers: re-estimating flux- and burial rates. International Journal of Earth Sciences 88: 599-606.

Sebag D, Disnar JR, Guillet B, Di-Giovanni C, Verrecchia EP, Durand A. 2006. Monitoring organic matter dynamics in soil profiles by 'Rock-Eval pyrolysis': bulk characterization and quantification of degradation. European Journal of Soil science 57: 344-355.

Simmonnet JP, Richy P, Pardon C. 1995. Contribution à l'étude des mécanismes et bilans de l'érosion chimique des Terres Noires du bassin de la Durance: exemple des bassins représentatifs expérimentaux de Draix (NE Digne). In Compte Rendu de Recherche en érosion et hydraulique torrentielle, 3, Cemagref (Ed). Antony : France; 189-199.

Stallard RF. 1998. Terrestrial sedimentation and the carbon cycle: Coupling weathering and erosion to carbon burial. Global Biochemichal Cycles 12: 231-257.

Tyson RV. 1995. Sedimentary Organic Matter: Organic Facies and Palynofacies. Chapman and Hall, London, 615 pp. 
Wakeham SG, Forrest J, Masiello C, Gaelinas Y, Alexander C, leavitt, P. 2004. Hydrocarbons in Lake Washington Sediments. A 25-Year Retrospective in an Urban Lake. Environmantal Science and Technology 38: 431-439. 


\section{Figures and Tables captions}

Fig. 1. Geographical location of Draix experimental watersheds (after Lopez Saez et al., 2011).

Fig. 2. $\mathrm{HI}\left(\mathrm{mg} \mathrm{HC} \mathrm{g}^{-1} \mathrm{TOC}\right.$ ) vs. Recent Organic Matter proportions (ROM \%) for 82 samples (Laval watershed). Uncertainties on HI values: $5 \%$; uncertainties on ROM proportions: $15 \%$.

Table 1. Rock-Eval 6 parameters (TOC and HI), ROM / FOM proportions, and ROC / FOC contents for 36 Laval riverine particles.(Suspended load (SL) and bed load (BL)).

Table 2. Rock-Eval 6 parameters (TOC and HI), ROM / FOM proportions, and ROC / FOC contents for 24 Moulin riverine particles.(Suspended load (SL) and bed load $(\mathrm{BL}))$.

Table 3. Sediment and FOC (mecFOC) yields for the Laval and Moulin watersheds.

Table 4. Dissolved load yield for Laval and Moulin catchments, $\mathrm{Ca}^{2+}$ and Total Dissolved Solid (TDS) concentrations in watershed waters (year 2002; after Cras, 2005). 
table 1

\begin{tabular}{|c|c|c|c|c|c|c|}
\hline Samples & TOC $\%$ & $\begin{array}{c}\mathrm{HI} \\
\left(\mathrm{mg} \mathrm{HC} \mathrm{g}^{-1} \mathrm{TOC}\right)\end{array}$ & $\begin{array}{l}\text { ROM \% } \\
(+/ .15 \%)\end{array}$ & $\begin{array}{l}\text { FOM \% } \\
(\% / .15 \%)\end{array}$ & $\begin{array}{c}\text { FOC wt. \% } \\
(+/ .15 \%)\end{array}$ & $\begin{array}{c}\text { ROC wt. \% } \\
(+/ .15 \%)\end{array}$ \\
\hline $\begin{array}{l}\text { Laval SL } \\
\text { 03/05/2002a } \\
\text { Laval SL }\end{array}$ & 0.55 & 25 & 8.2 & 91.8 & 0.5 & $<0.1$ \\
\hline $\begin{array}{c}\text { 03/05/2003b } \\
\text { Laval SL }\end{array}$ & 0.51 & 33 & 12.7 & 87.3 & 0.4 & 0.1 \\
\hline $\begin{array}{c}13 / 05 / 2002 \\
\text { Laval SL }\end{array}$ & 0.55 & 36 & 14.3 & 85.7 & 0.5 & 0.1 \\
\hline $\begin{array}{c}24 / 05 / 2002 \\
\text { Laval SL }\end{array}$ & 0.51 & 27 & 9.3 & 90.7 & 0.5 & $<0.1$ \\
\hline $\begin{array}{c}26 / 08 / 2002 \\
\text { Laval SL }\end{array}$ & 0.53 & 34 & 13.2 & 86.8 & 0.5 & 0.1 \\
\hline $\begin{array}{c}\text { 02/09/2002 } \\
\text { Laval SL }\end{array}$ & 0.52 & 27 & 9.3 & 90.7 & 0.5 & $<0.1$ \\
\hline $\begin{array}{c}\text { 05/09/2002 } \\
\text { Laval SL }\end{array}$ & 0.50 & 30 & 11.0 & 89.0 & 0.4 & 0.1 \\
\hline $\begin{array}{c}\text { 23/10/2002 } \\
\text { Laval SL }\end{array}$ & 0.55 & 24 & 7.6 & 92.4 & 0.5 & $<0.1$ \\
\hline $\begin{array}{c}\text { 06/07/2006 } \\
\text { Laval SL }\end{array}$ & 0.47 & 21 & 6.0 & 94.0 & 0.4 & $<0.1$ \\
\hline $\begin{array}{c}\text { 07/07/2006 } \\
\text { Laval SL }\end{array}$ & 0.56 & 25 & 8.2 & 91.8 & 0.5 & $<0.1$ \\
\hline $\begin{array}{c}\text { 12/07/2006b } \\
\text { Laval SL }\end{array}$ & 0.65 & 23 & 7.1 & 92.9 & 0.6 & $<0.1$ \\
\hline $\begin{array}{c}12 / 07 / 2006 a \\
\text { Laval SL }\end{array}$ & 0.56 & 20 & 5.4 & 94.6 & 0.5 & $<0.1$ \\
\hline $\begin{array}{c}\text { 18/07/2006b } \\
\text { Laval SL }\end{array}$ & 0.46 & 19 & 4.9 & 95.1 & 0.4 & $<0.1$ \\
\hline $\begin{array}{c}\text { 18/07/2006a } \\
\text { Laval SL }\end{array}$ & 0.51 & 20 & 5.4 & 94.6 & 0.5 & $<0.1$ \\
\hline $\begin{array}{c}\text { 08/09/2006 } \\
\text { Laval SL }\end{array}$ & 0.62 & 19 & 4.9 & 95.1 & 0.6 & $<0.1$ \\
\hline $\begin{array}{c}\text { 15/09/2006 } \\
\text { Laval SL }\end{array}$ & 0.52 & 25 & 8.2 & 91.8 & 0.5 & $<0.1$ \\
\hline $\begin{array}{c}\text { 25/09/2006 } \\
\text { Laval SL }\end{array}$ & 0.58 & 19 & 4.9 & 95.1 & 0.6 & $<0.1$ \\
\hline $\begin{array}{c}\text { 20/10/2006a } \\
\text { Laval SL }\end{array}$ & 0.54 & 26 & 8.8 & 91.2 & 0.5 & $<0.1$ \\
\hline $\begin{array}{c}\text { 20/10/2006b } \\
\text { Laval SL }\end{array}$ & 0.53 & 28 & 9.9 & 90.1 & 0.5 & 0.1 \\
\hline $\begin{array}{c}20 / 10 / 2006 c \\
\text { Laval SL }\end{array}$ & 0.52 & 29 & 10.4 & 89.6 & 0.5 & 0.1 \\
\hline $\begin{array}{c}\text { 07/12/2006a } \\
\text { Laval SL }\end{array}$ & 0.52 & 25 & 8.2 & 91.8 & 0.5 & $<0.1$ \\
\hline $\begin{array}{c}\text { 07/12/2006b } \\
\text { Laval SL }\end{array}$ & 0.52 & 23 & 7.1 & 92.9 & 0.5 & $<0.1$ \\
\hline $\begin{array}{c}\text { 04/06/2007 } \\
\text { Laval SL }\end{array}$ & 0.54 & 33 & 12.7 & 87.3 & 0.5 & 0.1 \\
\hline $\begin{array}{c}\text { 05/06/2007b } \\
\text { Laval SL }\end{array}$ & 0.60 & 32 & 12.1 & 87.9 & 0.5 & 0.1 \\
\hline $\begin{array}{c}\text { 05/06/2007a } \\
\text { Laval SL }\end{array}$ & 0.62 & 24 & 7.6 & 92.4 & 0.6 & $<0.1$ \\
\hline $\begin{array}{c}16 / 09 / 2007 \\
\text { Laval SL }\end{array}$ & 0.53 & 21 & 6.0 & 94.0 & 0.5 & $<0.1$ \\
\hline $\begin{array}{c}22 / 11 / 2007 \\
\text { Laval SL }\end{array}$ & 0.48 & 19 & 4.9 & 95.1 & 0.5 & $<0.1$ \\
\hline $\begin{array}{c}11 / 01 / 2008 a \\
\text { Laval SL }\end{array}$ & 0.61 & 23 & 7.1 & 92.9 & 0.6 & $<0.1$ \\
\hline $\begin{array}{c}11 / 01 / 2008 b \\
\text { Laval SL }\end{array}$ & 0.55 & 24 & 7.6 & 92.4 & 0.5 & $<0.1$ \\
\hline $\begin{array}{c}11 / 01 / 2008 \mathrm{c} \\
\text { Laval BL }\end{array}$ & 0.53 & 28 & 9.9 & 90.1 & 0.5 & 0.1 \\
\hline $\begin{array}{c}\text { 24/09/1999a } \\
\text { Laval BL }\end{array}$ & 0.49 & 14 & 2.1 & 97.9 & 0.5 & $<0.1$ \\
\hline $\begin{array}{c}\text { 24/09/1999b } \\
\text { Laval BL }\end{array}$ & 0.46 & 11 & 0.4 & 99.6 & 0.5 & $<0.1$ \\
\hline 24/09/1999c & 0.59 & 29 & 10.4 & 89.6 & 0.5 & 0.1 \\
\hline Laval BL & 0.42 & 14 & 2.1 & 97.9 & 0.4 & $<0.1$ \\
\hline
\end{tabular}


20/11/2006a

Laval BL

20/11

20/11/2006

18

4.3

95.7

0.4

$<0.1$

20/11/2006c

$22 \quad 6.5$

93.5

0.6

Average

0.53

7.7

92.3

0.5

$<0.1$ 
table 2

\begin{tabular}{|c|c|c|c|c|c|c|}
\hline $\begin{array}{l}\text { Samples } \\
\text { Moulin SL }\end{array}$ & TOC \% & $\begin{array}{c}\mathrm{HI} \\
\left(\mathrm{mg} \mathrm{HC} \mathrm{g}^{-1} \mathrm{TOC}\right)\end{array}$ & $\begin{array}{l}\text { ROM \% } \\
\left({ }^{+} / .15 \%\right)\end{array}$ & $\begin{array}{l}\text { FOC \% } \\
(+/ .15 \%)\end{array}$ & $\begin{array}{c}\text { FOC wt. \% } \\
(+/ .15 \%)\end{array}$ & $\begin{array}{c}\text { ROC wt. \% } \\
(+/ .15 \%)\end{array}$ \\
\hline $\begin{array}{l}13 / 05 / 2002 \\
\text { Moulin SL }\end{array}$ & 0.60 & 72 & 34.4 & 65.6 & 0.4 & 0.2 \\
\hline $\begin{array}{l}\text { 03/05/2002 } \\
\text { Moulin SL }\end{array}$ & 0.56 & 30 & 11.0 & 89.0 & 0.5 & 0.1 \\
\hline $\begin{array}{l}\text { 05/08/2002 } \\
\text { Moulin SL }\end{array}$ & 0.53 & 28 & 9.9 & 90.1 & 0.5 & 0.1 \\
\hline $\begin{array}{l}\text { 27/08/2002a } \\
\text { Moulin SL }\end{array}$ & 0.54 & 43 & 18.2 & 81.8 & 0.4 & 0.1 \\
\hline $\begin{array}{l}\text { 27/08/2002b } \\
\text { Moulin SL }\end{array}$ & 0.51 & 29 & 10.4 & 89.6 & 0.5 & 0.1 \\
\hline $\begin{array}{l}\text { 02/09/2002 } \\
\text { Moulin SL }\end{array}$ & 0.56 & 45 & 19.4 & 80.6 & 0.5 & 0.1 \\
\hline $\begin{array}{l}\text { 05/09/2002 } \\
\text { Moulin SL }\end{array}$ & 0.55 & 38 & 15.5 & 84.5 & 0.5 & 0.1 \\
\hline $\begin{array}{l}\text { 12/09/2002 } \\
\text { Moulin SL }\end{array}$ & 0.54 & 35 & 13.8 & 86.2 & 0.5 & 0.1 \\
\hline $\begin{array}{l}\text { 06/07/2006a } \\
\text { Moulin SL }\end{array}$ & 0.53 & 21 & 6.0 & 94.0 & 0.5 & $<0.1$ \\
\hline $\begin{array}{l}\text { 06/07/2006b } \\
\text { Moulin SL }\end{array}$ & 0.62 & 45 & 19.4 & 80.6 & 0.5 & 0.1 \\
\hline $\begin{array}{l}\text { 12/07/2006 } \\
\text { Moulin SL }\end{array}$ & 0.54 & 19 & 4.9 & 95.1 & 0.5 & $<0.1$ \\
\hline $\begin{array}{l}\text { 08/09/2006a } \\
\text { Moulin SL }\end{array}$ & 0.54 & 24 & 7.6 & 92.4 & 0.5 & $<0.1$ \\
\hline $\begin{array}{l}\text { 08/09/2006b } \\
\text { Moulin SL }\end{array}$ & 0.54 & 20 & 5.4 & 94.6 & 0.5 & $<0.1$ \\
\hline $\begin{array}{l}\text { 15/09/2006a } \\
\text { Moulin SL }\end{array}$ & 0.53 & 23 & 7.1 & 92.9 & 0.5 & $<0.1$ \\
\hline $\begin{array}{l}\text { 15/09/2006b } \\
\text { Moulin SL }\end{array}$ & 0.53 & 21 & 6.0 & 94.0 & 0.5 & $<0.1$ \\
\hline $\begin{array}{l}\text { 24/09/2006 } \\
\text { Moulin SL }\end{array}$ & 0.52 & 19 & 4.9 & 95.1 & 0.5 & $<0.1$ \\
\hline $\begin{array}{l}\text { 20/10/2006a } \\
\text { Moulin SL }\end{array}$ & 0.53 & 45 & 19.4 & 80.6 & 0.4 & 0.1 \\
\hline $\begin{array}{l}\text { 20/10/2006b } \\
\text { Moulin SL }\end{array}$ & 0.58 & 52 & 23.3 & 76.7 & 0.4 & 0.1 \\
\hline $\begin{array}{l}\text { 07/12/2006 } \\
\text { Moulin SL }\end{array}$ & 0.51 & 22 & 6.5 & 93.5 & 0.5 & $<0.1$ \\
\hline $\begin{array}{l}\text { 05/06/2007a } \\
\text { Moulin SL }\end{array}$ & 0.58 & 17 & 3.7 & 96.3 & 0.6 & $<0.1$ \\
\hline $\begin{array}{l}\text { 05/06/2007b } \\
\text { Moulin SL }\end{array}$ & 0.52 & 40 & 16.6 & 83.4 & 0.4 & 0.1 \\
\hline $\begin{array}{l}23 / 11 / 2007 \\
\text { Moulin SL }\end{array}$ & 0.53 & 21 & 6.0 & 94.0 & 0.5 & $<0.1$ \\
\hline $\begin{array}{l}\text { 12/01/2008a } \\
\text { Moulin SL }\end{array}$ & 0.58 & 33 & 12.7 & 87.3 & 0.5 & 0.1 \\
\hline $12 / 01 / 2008 b$ & 0.50 & 26 & 8.8 & 91.2 & 0.5 & $<0.1$ \\
\hline Average & 0.54 & 32 & 12.1 & 87.9 & 0.5 & 0.1 \\
\hline
\end{tabular}


table 3

\begin{tabular}{ccccc}
\hline & \multicolumn{2}{c}{ Laval } & \multicolumn{2}{c}{ Moulin } \\
year & $\begin{array}{l}\text { sediment } \\
\text { yield } \\
\left(\mathrm{t} \mathrm{km}^{-2} \mathrm{yr}^{-1}\right)\end{array}$ & $\begin{array}{c}\text { FOC } \\
\text { yield } \\
\left(\mathrm{t} \mathrm{km}^{-2} \mathrm{yr}^{-1}\right)\end{array}$ & $\begin{array}{c}\text { sediment } \\
\text { yield } \\
\left(\mathrm{t} \mathrm{km}^{-2} \mathrm{yr}^{-1}\right)\end{array}$ & $\begin{array}{c}\text { FOC } \\
\text { yield } \\
\left(\mathrm{t} \mathrm{km}^{-2} \mathrm{yr}^{-1}\right)\end{array}$ \\
\hline 1985 & 6188 & $\mathbf{3 1}$ & & \\
1986 & 10812 & $\mathbf{5 4}$ & & \\
1987 & 11288 & $\mathbf{5 6}$ & & \\
1988 & 7004 & $\mathbf{3 5}$ & 3564 & $\mathbf{1 8}$ \\
1989 & 4352 & $\mathbf{2 2}$ & 1350 & $\mathbf{7}$ \\
1990 & 12308 & $\mathbf{6 2}$ & 6534 & $\mathbf{3 3}$ \\
1991 & 9180 & $\mathbf{4 6}$ & 5346 & $\mathbf{2 7}$ \\
1992 & 21148 & $\mathbf{1 0 6}$ & 9990 & $\mathbf{5 0}$ \\
1993 & 11968 & $\mathbf{6 0}$ & 6156 & $\mathbf{3 1}$ \\
1994 & 18360 & $\mathbf{9 2}$ & 9396 & $\mathbf{4 7}$ \\
1995 & 9452 & $\mathbf{4 7}$ & 4374 & $\mathbf{2 2}$ \\
1996 & 17884 & $\mathbf{8 9}$ & 8424 & $\mathbf{4 2}$ \\
1997 & 8704 & $\mathbf{4 4}$ & 4536 & $\mathbf{2 3}$ \\
1998 & 7140 & $\mathbf{3 6}$ & 4590 & $\mathbf{2 3}$ \\
1999 & 9996 & $\mathbf{5 0}$ & 4590 & $\mathbf{2 3}$ \\
2000 & 13668 & $\mathbf{6 8}$ & 5562 & $\mathbf{2 8}$ \\
2001 & 8772 & $\mathbf{4 4}$ & 6588 & $\mathbf{3 3}$ \\
2002 & 12716 & $\mathbf{6 4}$ & 6642 & $\mathbf{3 3}$ \\
2003 & 15300 & $\mathbf{7 7}$ & 5130 & $\mathbf{2 6}$ \\
2004 & 17952 & $\mathbf{9 0}$ & 9180 & $\mathbf{4 6}$ \\
2005 & 13328 & $\mathbf{6 7}$ & 5670 & $\mathbf{2 8}$ \\
\hline Average & 11787 & $\mathbf{5 9}$ & 5979 & $\mathbf{3 0}$ \\
\hline & & & &
\end{tabular}

table 4

\begin{tabular}{cccc}
\hline catchment & $\begin{array}{c}\text { dissolved load yield } \\
(\text { Cras, 2005) } \\
\left(\mathrm{t} \mathrm{km}^{-2} \mathrm{yr}^{-1}\right)\end{array}$ & $\begin{array}{c}{\left[\mathrm{Ca}^{2+}\right]} \\
\left(\mathrm{Cras}^{2005)}\right. \\
\left(\mathrm{mmol} \mathrm{l}^{-1}\right)\end{array}$ & $\begin{array}{c}\text { average TDS } \\
(\text { Cras, 2005) } \\
\left(\mathrm{mmol} \mathrm{l}^{-1}\right)\end{array}$ \\
\hline Laval & 340 & 2.5 & 13.4 \\
Moulin & 570 & 2.4 & 11.7 \\
\hline
\end{tabular}


fig1
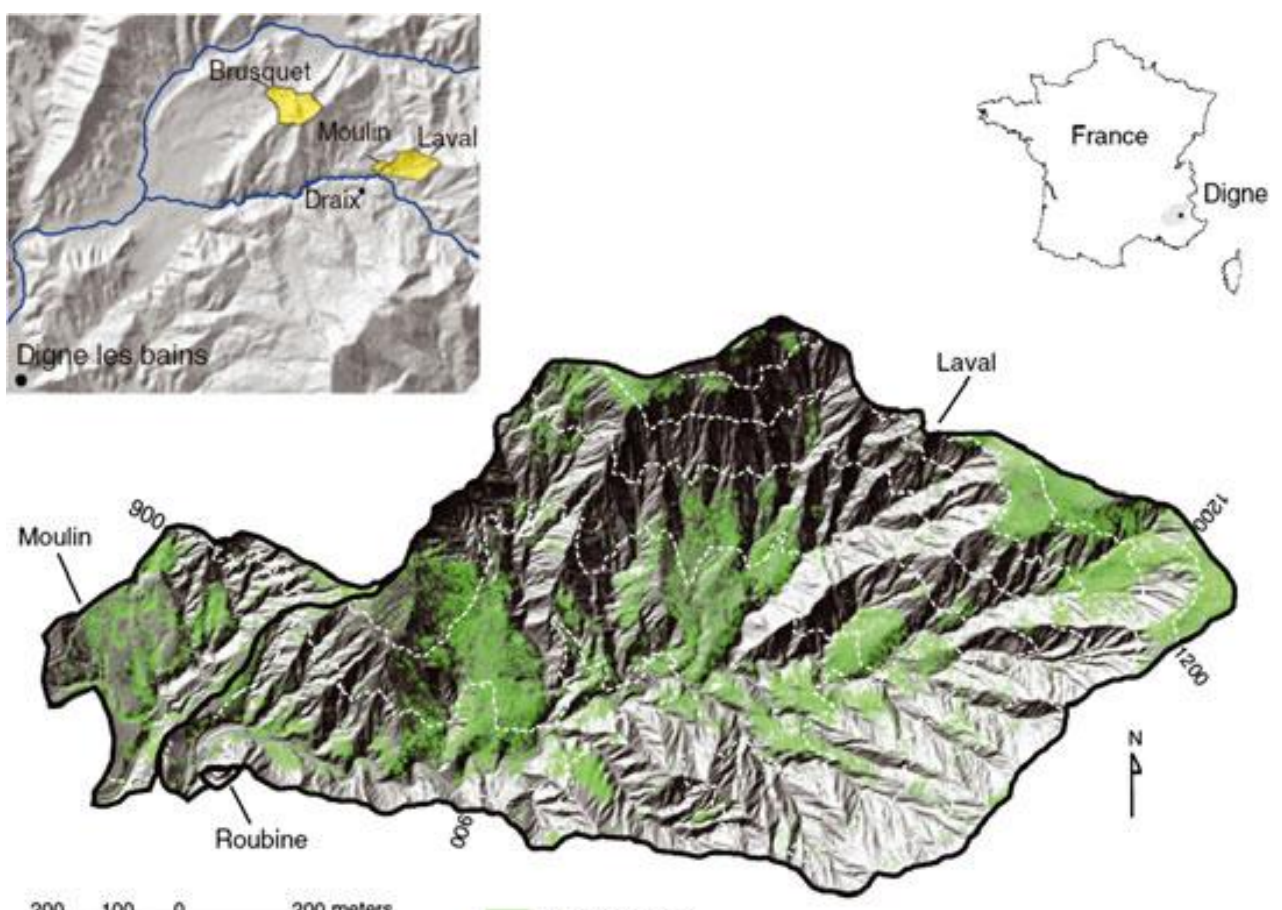

$200 \quad 100 \quad 0 \quad 200$ meters $\quad$ Forested area 
Fig2



